\title{
Educational Changes in the Process of So- cial Transformation from the Perspective of County: Taking Elementary Education in Dongtai in the Early Years of the Re- public of China as an Example
}

\author{
Hanyu Miao \\ Nanjing Normal University, Nanjing, China
}

\begin{abstract}
In the early years of the Republic of China, elementary education in Dongtai County was a microcosm of basic education at that time. The development of elementary education in Dongtai has twisted and developed under the background of the characteristics of civilian education, focus on moral education, support of squires, parallel between government and private affairs, and home-school liaison. As well as practical problems such as frequent personnel changes, restrictions on traditional private education concepts, and lack of teachers, it reflected the evolution of Chinese education in the early years of the Republic of China.
\end{abstract}

Keywords: Early Republic of China; Dongtai County; Elementary Education;

County Perspective; Educational Change

Correspondence to: Hanyu Miao, School of Fine Arts, Nanjing Normal University, Nanjing, China, Email:2389140601@qq.com.

Conflict of Interests: None. 


\section{The Social Background of the Rise of Elementary Ed- ucation in Dongtai in the Early Years of the Republic of China}

HERE are many related research articles on the history of education in China.
However, the content related to county education has not attracted enough at-
tention from the academic community, and the educational changes that have occurred in the social transformation from the perspective of the county are few. This study studied the running of Dongtai elementary education in the late Qing dynasty and early Republic of China, combined with the political economy and culture of the time, and placed it in the context of elementary education in Jiangsu province and even the whole country to analyze its characteristics. The commonality in the same vein highlights the individual reasons behind it. This study intends to describe the social background, general situation, development characteristics, and shortcomings of the rise of elementary education in Dongtai in the early Republic of China. It will research through the exploration and excavation of historical documents to fill the gap in the history of elementary education in Dongtai in the early years of the Republic of China, and then to explore one of the changes in education in the process of social change from the perspective of the county. At the same time, studying its characteristics and deficiencies and enlightenment can also provide some reference for the development of contemporary elementary education.

The research object of this study is the elementary education in Dongtai, Jiangsu in the early years of the Republic of China. It is better to say that it is the education situation in Dongtai in the late Qing Dynasty and the early Republic of China. Because the middle school education and Normal education in Dongtai area emerged as soon as possible in the 31st year of Guangxu in the Qing Dynasty (1905), the Republic of China was built, and the former middle school and normal school in Dongtai County were suspended immediately. In the end of the Qing Dynasty, Jian Zhang, the No. 1 champion, established a mother-teacher teacher in Dongtai, and Dongtai teacher education was restored. The restoration of Dongtai County Junior Middle School by the Dongtai County Office in 1924 marked the restoration of Dongtai Middle School education. Therefore, only the elementary education situation in Dongtai County exists in this historical section studied in this article, which can also reflect the entire situation of Dongtai education in the early years of the Republic of China.

The late Qing government promulgated the charter of local autonomy, promoted local autonomy in cities and towns, and implemented a system of county, city, and township autonomy. Its purpose is to "uphold political governance and down for peace", and "to help the inadequacy of government". I Until the founding of the Republic of China, the old system is still being used. The overall pattern of Dongtai County is 18 cities and 9 townships. Set up Dongtai, Hedu, Anfeng, Fuanxi, Fuandong, Liangdu, Nanxun, Daxing'an, Shiyan, Ercha, Sanlitze, Dingcao, Xiaohai, Shenzao City, Shenjiabang City, Qihu City, Haiyan City, Siantuan City, Qingpu Township, Xixi 
Township, Jiaoxian Township, Louzhuang Township, Tangganghe Dong Township, Baozhuang Township, Mengfenghe Township, Zhou Chen Xiang and Heluoyu Township count 27 cities and towns.

The history of Dongtai Elementary School can be traced back to 1902. According to the statistics of the "Dongtai County City and Township School Statistics Table"2 in the last three years of the Republic of China, there were 35 elementary schools in the county in the late Qing Dynasty, including 24 public schools and 11 private schools.

In the 28th year of Guangxu (1902), Anfeng Private Shanshan Junior High School and Dongtai Private Shanyu Junior High School founded in Guangxu 31st year (1905) were established the earliest. There are 12 elementary schools (including public and private), which are examples of Dongtai districts and have a certain scale. In the thirty-first year of Guangxu (1905), Bencha Qixiu Junior High School was established. Its predecessor was Qixiu Academy founded by Yingchen $\mathrm{Cai}^{3}$ in twenty-four years of Guangxu (1898). "Jiangsu Provincial Inspection Hours Assessment" (1913) states: "On the education development of the city and township, only the Bencha City is the most developed and the results are relatively good." 4

In the thirty-first year of Guangxu (1905), with the approval of the "Liangjiang Academic Affairs Office", the establishment of the official Dongtai School in Kuixing Tower, Taicheng on November 18 of that year marked the beginning of the earliest official school in Dongtai. According to Cheng Ji's "Diary of Lu Xuezhai", a teacher of the school, when the school opened, it only had a high school class. It was the earliest government high school class. The next year (1906), a middle school class was established. The county middle school and the attached high school hall were called "two halls" at that time, and the instructors were Cheng Ji, Qishou Chen ${ }^{6}$, Ruyu Chen ${ }^{7}$, etc. Xuan Tong third years (1911), the elementary school class was changed to a normal class, the school name was easily changed to "Dongtai County Middle School and Normal School", until the first year of the Republic of China (1912) the school was closed for some reason. The High School was relocated to Xixi Academy in 1911, and moved to the west of Taicheng Academy in 1912, and later became the first high school in Dongtai County.

The above school running situation was closely related to the rise of elementary education at that time. The late Qing and early Republic of China was the germination and development stage of modern education in China. The economic development and the influx of western democratic and free scientific thoughts made elementary education in the province prosperous.

According to "The Guangxu 27th (1901) on the second day of August, the provinces, prefectures, Zhili prefectures, and prefectures and counties reorganized the colleges into elementary, middle, and elementary schools", the purpose of consolidating "talents as the foundation of government affairs" 8 was ordered to reorganize academies and schools of justice across the country. The "Ren Yin School System" and "Gui Mao School System" have preliminarily established the national education tenet of "middle school as the body and western learning as the use" and "loyalty to the monarch, respect for Confucianism, respect for martial arts, and authenticity". The abolishment of the 
imperial examination system and the promulgation of the "School Charter for Women's Elementary Schools" formed a complete school system of elementary education based on the idea of "founding the country", and paved the way for the transition and development of modern education to modern education.

According to "Jiangsu Province Chronicle - Education Chronicle": "In the 33rd year of Guangxu (1907), there were 1,632 elementary schools in Jiangsu Province, including 217 second-class elementary schools, 91 advanced elementary schools, 1,105 elementary elementary schools, and half-day school 123. There are 96 women's schools. The total number of students is 49,921."9

According to the "Dongtai County Chronicle", in the 31st year of Guangxu (1905), Jiangsu Province ordered Dongtai County to establish a county school office. In 1907, the Dongtai Society was changed to the Dongtai Education Association, and the Dongtai School Office was changed to a persuasive school. ${ }^{10}$ At this time, the setting of elementary schools in Dongtai County was a peak in the years after the thirty-first year of Guangxu (1905), and emerged one after another.

The third year of Xuantong (1911), the Revolution of 1911 broke out. Dongtai, Jiangsu is located in the middle of Jiangsu Province, facing the Yellow Sea in the east, Yancheng in the north, Taizhou in the west, and Nantong in the south. Peace was restored under the efforts of enlightened squires led by Gongfu Yang ${ }^{11}$ and Litang Ding ${ }^{12}$. Due to the chaos at the turn of the times, at the beginning of the reform, most of the elementary education in Dongtai County was facing stagnation, and there was an urgent need to reform and establish a group of elementary schools to meet the needs of the current development. In the first year of the Republic of China (1912), Jiayu Qiu, a native of Dongtai, served as the teaching faculty member of the first high school in Dongtai County.

Yulin Cui $^{13}$, the principal of Dongtai County First High School at the time, said: "After the recovery of Wuyi, the county school was only a high school, and the rest of the city and township education, except Bencha City, have no perspective. The popularity of education is difficult." 14 This showed the general situation of elementary education in Dongtai County in the early years of the Republic of China. Qiu Jiabiao said, "Overviewing the education status of the counties in the province is changing with each passing day, and the Xishan River in the south of the Yangtze River and the Chongchuan River in the North of the River have made progress in a thousand miles, and there has been great development." 15 At this time, the education of Dongtai County was far less than that of South Yangtze River, which was guaranteed by the flourishing economy and culture, but compared with the momentum of "one thousand miles a day" education in Nantong and Rugao, the neighboring counties in the same north, there was also a gap. Restoring the old school and setting up a new school has become a top priority for Dongtai education at this time. In the first year of the Republic of China (1912), the Ministry of Education promulgated the General Order on Interim Measures for General Education and the Standards for Interim Courses on General Education. In April of the same year, Yuanpei Cai's "Opinions on Educational Guidelines" and subsequent education conferences determined the education of "emphasis on moral educa- 
tion, supplemented by utilitarian education, military-national education, and aesthetic education". ${ }^{16}$ The purpose embodies the educational thought of the comprehensive development of moral, intellectual, and physical beauty. In September 1912, the Ministry of Education promulgated the "Elementary School Decree", which aims at "paying attention to children's physical and mental development, cultivating the foundation of national morality, and giving them the knowledge and skills necessary for life."

\section{A Survey of Dongtai Elementary Education in the Early Years of the Republic of China}

According to the "Statistical Table of Schools in Dongtai County", 17 the third year of the Republic of China (1914), there were 77 schools in all cities and towns in Dongtai County. Among them, there are 2 county schools, which were established in the first year of the Republic of China (1912) in the first high school of Dongtai County in November in the first year and in the second year of the Republic of China (1913) in Dongxiang Old Town. There were 76 students in Dongtai County First High School, 60 people in Dongtai County Girls Junior High School including 29 juniors and 32 seniors. There were 58 township schools in the city. Dongtai City in the urban area includes the first, second, third, fourth, fifth, sixth, and seventh elementary schools in the city, and Hedu City in the urban area includes the first, second, third, and fourth elementary schools in the city. The size of Bencha City was the same as that of Dongtai City. Secondly, Anfeng City, about thirty miles southeast of Dongtai County, included one municipal elementary school, and one each for the first and second elementary schools. Totally, there were seventeen private schools. Three urban districts are private Shanyu Junior High School, private Weidong Junior High School, private Qidong Women's Junior High School; two Anfeng schools, private Shanshan Junior High School, and private Xixi Elementary School; two Nanxun Elementary Schools, It is a private Longtan, Longtan Women's Elementary School; seven teas, private Miao's, Xu's, Cai's, and civilian elementary schools, private Cai's Junior High Junior High School, private Cai's Girls, Cai South South Elementary Elementary School; Daxingcheng City There is one private Shihua Junior High School; Qingpu Township has two schools, which are private Zhenxin Junior High Schools and private Qixiu Girls High Schools. There are no elementary schools in the four districts of Xiaohai City, Shenzao City, Haiyan City, and Xixi Township. In the three years to the Republic of China (1914), there were 2,145 students in Dongtai County, 1,669 junior students, 329 senior students, 112 female junior students, and 35 female senior students.

In the third year of the Republic of China (1914), Shikai Yuan restored the imperial system, on the ground of "the Chinese national situation is different from other countries, and it is difficult to adopt a foreign autonomy system. If self-government is a complete auxiliary organ of official governance, and autonomy may not be developed," 18 it was forced to order the provinces' local self-government systems were suspended. That year, Hongjun Lu dispatched Governor Dongtai as the fifth governor of Dongtai after Baoyin Yang, Nian Yang, Qingchang Luo, and Xueyi Cheng. 19 "Hongjun 
came to know that when the autonomy ceased, everything was in order, and there was no lack of delay. Fortunately, the people were enthusiastic about public welfare and carried on as usual in the education department. Schools in various cities and towns have been promoted and gradually completed. ${ }^{20}$ He left office in July 1914 the following year. The sixth county chief Suizhi Yan inspected the situation of elementary schools in Dongtai County, and analyzed the necessity and importance of Yiyi's elementary education. "Education is the foundation of a nation, and elementary schools are the foundation of all education. There are countries in every civilization of the world. There are schools in the world. We must pay attention to elementary schools as a source of talent." 21 At this time, the establishment of the elementary school in Dongtai County has begun to take shape compared with the predicament of the first year of the Republic of China. "Fortunately, the Yi Elementary School has been established and has a scale. With the promotion, the basics of national education are all right.",22

According to the third year of the Republic of China (1914): see Table 1.

\section{Characteristics of the Development of Elementary Education in Dongtai in the Early Years of the Re- public of China}

\section{Education Focus Shifts to Civilians}

Since modern times, Western learning has gradually spread to the east, and the popularity of education has been extended and developed in the exploration. Under the intense social changes in the late Qing Dynasty and the early Republic of China, the focus of education dropped to the civilian class.

According to "Dongtai County Chronicle" (1817-1911), "Dongtai County Chronicle of Events", in the first year of Guangxu of the Qing Dynasty (1875), Dongtaichang Salt Merchants donated a Peiying Yixue School. ${ }^{23}$ In the 28th year of Guangxu of Qing Dynasty (1902), Peiying Elementary School, the first school in Dongtai County, was established. ${ }^{24}$ In the third year of the Republic of China (1914), the Dongtai County Office proposed that this specific measure be prioritized by the county and township school directors for the popularization of education. In the "Educational Situation of Dongtai County", it is emphasized: "Educators in Dongyi cities and towns are enthusiastic in education, and they have outstanding achievements. However, the prosperity of education must be universal. The establishment of schools is not tiresome. Gou Nengdu promotes, on average, two schools per city and one school per town. Since then, but within four years, the county school district can be fully established. And school-age children have never lost school. ${ }^{25}$ At the same time, the city and township school directors put forward four requirements that must be prioritized in education: that in addition to planning and controlling related funds, school-age chil- 


\begin{tabular}{|c|c|c|c|c|}
\hline $\begin{array}{l}\text { School } \\
\text { Name }\end{array}$ & $\begin{array}{l}\text { County First High } \\
\text { School }\end{array}$ & $\begin{array}{l}\text { County Girls' } \\
\text { Middle School }\end{array}$ & $\begin{array}{l}\text { Private Shanyu } \\
\text { Middle School }\end{array}$ & $\begin{array}{l}\text { Private Victoria } \\
\text { School }\end{array}$ \\
\hline Established & $\begin{array}{l}\text { The first year of the } \\
\text { Republic of China } \\
\text { (1912) November }\end{array}$ & $\begin{array}{l}\text { The Republic of } \\
\text { China (1913) } \\
\text { January }\end{array}$ & $\begin{array}{l}\text { Thirty-one Years of } \\
\text { the Guangxu Period } \\
\text { of Qing Dynasty } \\
\text { (1905) }\end{array}$ & $\begin{array}{l}\text { The first year of } \\
\text { the Republic of } \\
\text { China ( } 1912 \text { ) }\end{array}$ \\
\hline Address & West of School Palace & $\begin{array}{l}\text { East Lane Guard } \\
\text { Camp }\end{array}$ & Jishantang & $\begin{array}{l}\text { Guangji Bridge } \\
\text { South }\end{array}$ \\
\hline Principal & Cui Yulin & $\begin{array}{l}\text { Yuan Yushan, } \\
\text { Zhao Yushan }\end{array}$ & Zhou Guojiang & Shen Jizhou \\
\hline $\begin{array}{l}\text { Teaching } \\
\text { Staff }\end{array}$ & $\begin{array}{l}\text { Lu Xinlu, Du Ji, Wang, } \\
\text { hiying, Zhai Jun, Zhou } \\
\text { Zhiding, Sun Yan }\end{array}$ & $\begin{array}{l}\text { Zhang Shaotang, } \\
\text { Zhai Chengyi, } \\
\text { Zhang Liu Jingqi }\end{array}$ & $\begin{array}{l}\text { Zhou Guojiang, Ren } \\
\text { Houzhen, Zhou } \\
\text { Zhiping, Miao } \\
\text { Xiping }\end{array}$ & $\begin{array}{l}\text { Shen Jizhou, } \\
\text { Wang Yongnian }\end{array}$ \\
\hline $\begin{array}{l}\text { Total Stu- } \\
\text { dent \# }\end{array}$ & 76 & $\begin{array}{l}\text { 60: Elementary } \\
29, \text { Higher } 31\end{array}$ & $\begin{array}{l}\text { 52: Elementary 22, } \\
\text { Higher } 30\end{array}$ & $\begin{array}{l}\text { 63: Elementary } \\
33, \text { Higher } 30\end{array}$ \\
\hline $\begin{array}{l}\text { School } \\
\text { Year }\end{array}$ & Three years & Two years & Two years & Two years \\
\hline $\begin{array}{l}\text { School } \\
\text { Time }\end{array}$ & $\begin{array}{l}30 \text { Class hours per } \\
\text { week in first grade; } 33 \\
\text { class hours per week } \\
\text { in the second grade }\end{array}$ & $\begin{array}{l}\text { Elementary } 26 \\
\text { hours per week; } \\
32 \text { lessons per } \\
\text { week }\end{array}$ & $\begin{array}{l}\text { Elementary } 25 \\
\text { hours per week; } 30 \\
\text { class hours per } \\
\text { week }\end{array}$ & $\begin{array}{l}\text { Elementary } 25 \\
\text { hours per week; } \\
30 \text { class hours per } \\
\text { week }\end{array}$ \\
\hline $\begin{array}{l}\text { Annual } \\
\text { Budget }\end{array}$ & 3,072 yuan & 1,200 yuan & 1,100 yuan & 1,023 yuan \\
\hline
\end{tabular}

dren in the city and township must be identified to promote the city and township schools.

With the conflict between western industrial civilization and Chinese traditional culture, some advanced intellectuals became more aware of the country's social crisis. The understanding of the West has gradually shifted from the military and technical level of the Westernization Movement to the ideological level. From "teachers to improve their skills through control" to "teachers to improve their skills through selfimprovement", they have increasingly realized the importance of opening up the wisdom of the people. The first step to open up the wisdom of the people is to face the bottom of the society and move towards civilians, so that those who are unable to go to scholars or scholars who have lost their education or even have a low level of education can obtain corresponding education. Through the popularization of education, more and more citizens will accept the corresponding knowledge and culture.

\section{Establishing Morality and Emphasizing Moral Education}

Moral education is especially important for students who have not yet formed their personal values, so the importance of moral education in elementary education is reflected here. As Yuanpei Cai said in his "Opinions on Educational Guidelines": "What is citizen morality? The French Revolution was for free, equal, and love. The essence of morality is the best. The three are the root of all morality and everything about citizenship moral education.,"26 
Take the example of a self-cultivation lesson of the first year of the county elementary school in August of the second year of the Republic of China (1913). The textbook used by the teacher Lu Xinlu in the class is the first volume of the selfcultivation textbook published by the book company. Lesson "Fortitude". From the inspection records of the county inspection at the time, it can be seen that: Lu Xinlu's "mildness, sincerity, and sincerity in teaching", "using development-oriented questionand-answer, and finally to develop resilience, don't be afraid to persevere." Napoleon The marching example inspired the self-sustaining nature of children. "A march goes, everything goes. Napoleon was like this, and no one cannot be like this."27 In January of the third year of the Republic of China (1914), the teacher Shu Di taught a selfcultivation course for the school's one-year student. The textbook used was the second volume of "Self-cultivation" published by the Commercial Press. Instructor Shu Di "the teaching materials are very easy to use, and can focus on movement, which is in line with the essence of self-cultivation., ${ }^{28}$ And training in the professor, not only increase children's knowledge, but also cultivate character.

In the early years of the Republic of China, elementary school moral education was mainly reflected in the setting of self-cultivation. During this period, the educational purpose of the self-cultivation course in elementary schools changed from the traditional moral education of "loyalty, filial piety, and justice" to the moral education of citizens. In the first year of the Republic of China (1912), the Nanjing Provisional Government deleted "loyalty" and "respect for Confucius" in its educational purpose. The "self-cultivation" curriculum in the elementary school emphasized virtues such as filial piety, faithfulness, courage, frugality, hard work, and cleanliness. ${ }^{29}$ At the same time, the Ministry of Education issued a new educational purpose: "Emphasis on moral education, supplemented by practical education, military education, and aesthetic education to complete its morality., ${ }^{30}$

\section{Supplementary Funding, Squire Support}

In the early years of the Republic of China, under the real situation of severe shortage of government education funding, the state advocated "education autonomy", that is, to encourage private capital to run schools. During this period, local education funding relied heavily on the support of squires everywhere, and Dongtai was no exception.

After the Revolution of 1911, the former Dongtai County and Dongtai School Supervisor Yuantai $\mathrm{He}^{31}$ fled with the funds, resulting in a financial deficit in the Civil Affairs Department of Dongtai County and a serious shortage of education and financial funds in Dongtai County.

As the county education inspection Qiu Jiazheng said in the inspection report of the state of education in Dongtai County in the second year of the Republic of China:

"Chadong County has education funding, which includes basic income and taxes every year. However, it will cost more than 7,000 yuan (Currency of the former Republic of China). In the future, county schools will gradually be established. Without a rice cook, a clever woman cannot do it. Instead of digging into thirst, why not plan 
ahead. This county has education funding, but also the urgent task today. There are basic assets and miscellaneous donations. It is proposed that in addition to the original $40 \%$ of the additional tax, the county public office will plan the budget. For details, check and execute by inspection history. Chadong Education's old basic products and various miscellaneous donations were lost. Non-strict is buried, not enough to rectify. It is planned to expand each of them separately., ${ }^{, 32}$

With regard to planning for urban and rural education funding, Article 2 of the "Amendments to the Regulations for Planning the Educational Costs of Counties, Towns, and Villages" specifically proposes the sources of planning for urban and rural education funding: the original tax and miscellaneous donations, public funds and public property of the municipal and rural governments, and county financial appropriations. And squire support. In addition, while cleaning up the basic assets of urban and rural education, additional taxes and special taxes will be levied, as well as miscellaneous donations of consumables such as tin foil and cigarettes. The arrangement and expansion of education funds provide a strong guarantee and a solid foundation for the normal operation of the school. Take for example the control of school funding for county elementary school teacher's workshops and higher schools: Table 2.

Since the Song Dynasty, the school field system, which has emerged as the times of the imperial examination system, has continued. That is, the school field under the control of academics, teachings and other local officials earns funds in the form of rents to support the local school academies' maintenance expenses. Dongtai was originally a Taizhou territory of Yangzhou Prefecture. In the $33^{\text {rd }}$ years of the Qing Dynasty in Qianlong (1768), Dongtai was separated from Taizhou to establish a county. "In the thirty-three years of Qianlong, it was agreed that Taizhou, a government of Yangzhou, Jiangnan, should be divided into Dongtai County shortage, three years of tribute.",33

In addition to the adjustment of the school's student staffing, Taizhou should be assigned to more than 800 acres of school fields in the newly established Dongtai County, and the rents collected should be used as education funds for the newly established Dongtai County school. However, Taizhou has not delivered to Dongtai, and since the establishment of Dongtai County, Dongzhi County has not mentioned it. The Republic of China was established, and Yang Gongfu, the first civil affairs chief of Dongtai County, discovered the matter from the old archives, and sent a commissioner to Taizhou to investigate and deal with the matter. Under the ruling of the Yangzhou military government, the corresponding school field was finally recovered from Taizhou. The 143-year-old Xuetian account has been clarified since Dongtai County was established. This move spread the word in the academic circles at that time, and also made a significant contribution to the transformation of the education system in Dongtai in the early years of the Republic of China and the development of education.

At the same time, the development of elementary education in Dongtai in the early years of the Republic of China was inseparable from the support of the gentry school board represented by Yinguan Xia, Ji Cheng, Huai Wang ${ }^{34}$, and Rong $\mathrm{Lu}^{35}$. Xia Guanghou, the son of Yinguan Xia, recalled his father's support for running the school. The text said: "In the first year of the Republic of China (1912), the private 


\begin{tabular}{lll}
\hline \multicolumn{2}{l}{ Table 2. School Funding. } \\
\hline & $\begin{array}{l}\text { Elementary School } \\
\text { Teacher's Workshop }\end{array}$ & Primary School \\
\hline First Level Apprentice & 1,360 Yuan & 320 Yuan \\
\hline Faculty & 180 Yuan & 90 Yuan \\
\hline Staff Meal & 160 Yuan & 60 Yuan \\
\hline School Fee & 300 Yuan & 80 Yuan \\
\hline Daily Expenses & 200 Yuan & 50 Yuan \\
\hline Reserve Fee & 2,200 Yuan & 600 Yuan \\
\hline Total & 3,500 Yuan & 1,000 Yuan \\
\hline Second Level Apprentice & 4,600 Yuan & 1,300 Yuan \\
\hline Tertiary Apprentice & \\
\hline Note: Yuan is the unit of the currency of the former Republic of China. & \\
\hline
\end{tabular}

Huainan School of Law and Politics was founded in Taicheng and closed three years later. He then served as a high school supervisor for three years. Difficult, he donated 2,300 yuan and donated over 2,700 yuan of salaries for the post of director of Dongtai Middle School, and donated a total of more than 5,000 yuan. Therefore, he was recognized by the Ministry of Education and awarded the first-class golden medal.",36

The establishment of educational associations, publicity clubs, newspapers and newspapers and other institutions also played a certain role. The Dongtai County Education Association was presided over by Rong Lu, who later became the editor-in-chief of the "Dongtai County Chronicle". Cheng Ji served as the vice chairman of the Dongtai Heduo Education Association. Liu Xun served as the chairman; Huai Wang the finance director of the county office in the early years of the Republic of China, served as the academic committee member; Yingchen Zhou, a graduate of Lianghuai Middle School and a former teacher of Dongtai Yizheng Industrial School, served as an academic committee member.

\section{The Rise of Private School, Public and Private Parallel}

At the end of the Qing Dynasty and the beginning of the Republic of China, government-run schools could not meet the needs of the society, so a number of private schools spearheaded by the Chinese people sprung up. The Qing Government's "Statutes of the Kindergarten Elementary School" encouraged officials and gentry and citizens to run schools independently. In the second year of Xuantong (1910), the Ministry of Qing Dynasty promulgated the "Improvement of Private School Regulations", "If the number of students is more than 30 , the annual fundraising should be submitted in detail as a private elementary and higher school. ${ }^{37}$ In time, private schools that have reached a certain scale have undergone transformation.

Taicheng Private Shanyu Junior High School was founded in the 31st year of Guangxu (1905), and was reorganized in January of the 2nd year of the Republic of China (1913). Its address was in Jishan Hall at Taicheng. The principal was Guojiang 
$\mathrm{Zhou}^{38}$, and the teachers were Ziwei Miao ${ }^{39}$, Yaofu Ren ${ }^{40}$, Zhiping Zhou, etc. In terms of practical textbooks, the textbooks published by Zhonghua Book Company were not limited to them. Instead, they were selected by teachers, or adapted, or written by themselves. They noted the combination of old and new, combining traditional ancient teaching motto with fresh knowledge taught. The teaching equipment is advanced and the teaching environment is superior to that of ordinary schools.

From the second year (1913) to the third year of the Republic of China (1914), the county's first, second, and third school teaching conditions were reviewed and reviewed. "Curriculum development was very legal. School buildings had everything and good equipment, and it was the crown of Dongtai. All the content was improving day by day. All professors could adopt the development style. The training was honest and diligent. It was very appropriate. Students were in school, neat and serious, and the management was well-characterized. On the back of the classroom, more windows were opened for easy access. Ventilation was very good for health. Lined in and out for the class, game breaks, and teacher supervised. Each level had a password for the director." ${ }^{, 11}$ In the review of the provincial inspection, it was stated that: "The teacher's selfcultivation, moral character, and more about daily behaviors, as well as the ancient teaching motto, are quite practical. The national language changed is also meticulous." 42

Taicheng private schools are mostly located in the middle of Cross Street. There are Jishantang's private Shanyu Junior High School, Guangjiqiaonan Private Weidong Junior High School, and Dayuetang's private Qidong Girls' Elementary School. The scale of running these private schools was among the best in the county's education industry.

\section{Home Education, Home and School Communication}

In particular, it should be noted that in the late Qing and early Republican period, schools in Dongtai emphasized the need for schools to connect with families in family education, and focused on the cultivation of living ability. This theory and corresponding measures could be put forward a hundred years ago. It can be seen that Dongtai Education in the early years of the Republic of China was quite forward-looking.

Home education serves as the foundation of school education and social education. Words and deeds of parents in the family in the family, the mutual influence between family members undoubtedly played an important role in children.

In the "State of Education in Dongtai County", a corresponding discussion was launched: "Schools have a close relationship with the family. If you want to receive training to achieve results, it is not the school and the family. You can't do anything to complement each other, why not? I come to school only six days a week and five or six hours a day. If home education is not the same as the school's purpose, how hard it is for teachers to pay for it. ${ }^{, 43}$

Students are the link between the home and the school, so it is necessary to connect the family in education. The methods of contacting the family include: "1) of- 
ten investigate the situation of children's families; 2) gather the father and brother of the children to visit the professor, or have a talk with the father or brother, or visit the exhibition of student apprenticeships; 3) notify the children of each family The book is a temporary or regular notice; 4) Keep the children's self-cultivation book and report the main points of the school's dictation to the family; 5) Keep the children's diary on the next day and holidays and present it to the teacher for review and to inform the family situation." $^{\text {"44 }}$

In the first year of Xuantong (1909), Dongtai County Industrial School was established, and Baoshu Di served as the dean. Later, another type of industrial school was established, and manual, arithmetic, business, and gymnastics courses were added. As the county inspector Jiabiao Qiu said:

"Suppressing today's education, why is it about education? It is also the time to break the two-dimensional education of plane education and gradually change the physical education of two-word education. When youth are in school, learn for life, not for school, Western philosophy it has been discussed in detail. Our country's elementary school order, also known as giving the knowledge and skills necessary for life, is about skills? What is necessary for life? Everything is practical. For example, the manual subject is a technical subject. Although it is placed in random subjects, however according to what has been said recently, it is necessary for practical schools. If you pay attention to manual work, you can develop the habit of hard work, which is in line with the purpose of today's education. It can also create physical objects to prepare for other careers. You can also know what you want."45

Emphasis on the cultivation of living ability, emphasizing pragmatism is reflected in the innovative level of teaching content. In addition to the general Chinese language, arithmetic, self-cultivation, singing, and drawing, the teaching content includes English, self-study, gymnastics, and games. Reasonably plan the teaching time, with a maximum of 28 teaching hours per week for elementary and elementary schools and a maximum of 30 teaching hours per week for higher and elementary schools. The teacher pays attention to the physical and mental development of the students, and supervises them to increase a certain amount of sports and game time after class. Teachers focus on questioning and developing teaching. These coincide with the quality education that attaches great importance to the ideological and moral construction of the trainees, strengthens the cultivation of living ability, promotes the healthy growth of the body and mind, and emphasizes the comprehensive development of personality.

Quality education aims at improving national quality, comprehensively improving the basic quality of students and promoting their comprehensive development. Elementary education is the foundation of the entire education cause, and it is the top priority of basic education. Therefore, we must strengthen the quality education of elementary students.

During a fierce social change process like the late Qing Dynasty and the early Republic of China, we not only saw the changes in education, but also the importance that people attach to education, especially elementary education in basic education. Taking this step well is not only related to the improvement of national quality, but also 
to the national rejuvenation. Students are the hope of the motherland, the future of the nation, and the growth of students is related to the development of society and the prosperity of the country. Good elementary education is essential for children who have not yet cultivated the correct values of life, and it can lay a solid foundation for each elementary student to develop and succeed in the future. Therefore, the importance of elementary education must be taken seriously.

\section{Insufficient Elementary Education in Dongtai in the Late Qing Dynasty and Early Republic of China}

The emergence of new elementary education in Dongtai City in the late Qing Dynasty and the early Republican period is not only an inevitable result of the times, but also the desire of the Chinese people for education and the pursuit of knowledge. It is also an important step for the nation to rejuvenate. We can see that the changes in educational concepts, the innovation of teaching content, the rising of more and more private schools, and so on. All of this cannot be separated from the timely supplementation of a large amount of education funds and the full support of enlightened gentry and education groups. The experience of Dongtai elementary school education in the late Qing and early Republican period has certain reference significance for our school's teaching philosophy, school management, and teacher construction.

The lack of elementary education in Dongtai in the late Qing Dynasty and early Republic of China mainly includes the following aspects:

First, the changes in personnel of the education administration agencies and their negligence have hindered the progress of elementary education in Dongtai County, which is under development.

According to "Jiangsu Province Inspection Evaluation Case" in the second year of the Republic of China (1913), it stated that: Administrative agencies are continuously changed. The staff of the third section, in addition to the county inspections appointed in the early summer of this year, is still able to inspect the competent staff; the section chiefs have changed hands three years. The reorganization was engraved, and the third section was temporarily handled by Bao. However, when things are perfunctory, it is difficult to disappoint everyone. Since then, there is no enthusiastic and educated person with profound education to preside over the plan, supervise the promotion, and fear that the whole school will not be developed. Although many city and township public schools and academic committees have been established, according to actual conditions, there are no achievements at all. ${ }^{46}$ In the early years of the Republic of China, education administrators pushed each other's urgency and bureaucracy, administrative system personnel changed frequently, and various changes in policies have affected the emerging development of Dongtai elementary education.

Second, the impact of the private education system objectively caused some resistance to the development of the emerging elementary education in Dongtai.

After the establishment of Dongtai County, it is one of the eight counties of Yangzhou Prefecture, and its geographical location is far away from the sea slugs. 
Therefore, it has never been affected by the soldiers. At the same time, the prosperity of Huainan Zhongshichang's salt industry has brought about great economic development and gave birth to a prosperous cultural movement. According to the statistics of the list of Dongtai County Chronicle, there are 17 Jinshi, 46 Juren, 62 Linsheng, 134 Gongsheng, 89 Jiansheng, , 22 Zengsheng Fusheng, 6 Wujinshi, and 26 Wujuren. ${ }^{47}$ Until the 1940s, there were still a lot of talents in the county. The average age is around sixty or seventy. Here is an example:

According to Mr. Lian Miao recalled: "In the 32nd year of the Republic of China (1943), I went to Xiafu, Caiyi Street, to attend the ceremony of the funeral of Guangxu Hanlin Xia Yin's official. My grandfather, Jiayi Zhou ${ }^{48}$ (name You Liang), served as the main sacrifice, and my aunt and grandfather were the father-in-law, the uncle, the uncle Dongping, the uncle Kunzhong, and the father-in-law, Mrs. Zhou Rulan. I brought him there. It's very lively and magnificent. Remember when Xuan Lao was a talented man who lived in Jinjiadun."

After the establishment of the Republic of China, some old gentlemen who participated in the imperial examinations mostly established apprenticeship at home. With their local prestige, they attracted a large number of middle-class businessmen and families, sending their children to these old gentlemen. The reason is nothing more than a wait-and-see attitude towards new schools and admiration for famous teachers.

The halls opened by these highly respected old gentlemen are not targeted at school-age children, but students who have been studying in the private hall for several years. This undoubtedly gave rise to the rise of private monks in ordinary Mongolian museums, and the two can be described as interacting. Under the influence of this factor, both the Mongolian Museum and the Economic Museum appear to be flourishing in Dongtai City where businessmen gather. It can be seen that during the Republic of China, the coverage of private education in Dongtai County was extensive.

Teaching students according to their aptitude is a consistent teaching method in traditional Chinese education. Under private Chinese education, it is unnecessary to say a lot. At the same time, in the reform of the elementary school education system in the late Qing Dynasty, it was also emphasized: that is to say, "the talented and intelligent" Each had its own requirements, and treats "those who are too blunt to remember," and "those who have poor memory but still understand it well." 49 After the 1911 Revolution, with the influx of democratic thoughts, the educational concept of teaching students according to their aptitude has infused more aspects of focusing on pragmatism and individualized education on the basis of previous ones.

In the early years of the Republic of China, there was another noteworthy phenomenon in the field of education in Dongtai. Many of the principals and teachers who taught in new schools in the late Qing Dynasty and the early Republican period were either due to personnel changes, family reasons, or personal mentality changes. Leave from the school teacher position, return to open a home to run a school, or invited by wealthy families to serve as a tutor. As described in the "Dual Structure of Private Schools and Education" in "The History of Chinese Private Schools"50: The dual structure of private schools and public schools was actually a reflection of the old and new 
Chinese society and education." The two are complementary. It is still mutually restrictive. At present, the author believes that it is not yet possible to define a specific definition. At least, the private system has objectively created a certain resistance to the development of the emerging Dongtai elementary education, but it is undeniable that this coexisting dual structure it undoubtedly meets the individual needs of socially educated groups.

Third, the shortage of teachers is not directly proportional to the growing number of students.

Under the new education system in the late Qing Dynasty and the early Republic of China, a large number of schools emerged. The first thing to consider is the teaching staff. The source of teachers becomes the elementary issue. Looking at the birth comparison chart of principals and teachers in elementary schools in Dongtai County, cities and towns in the early years of the Republic of China, at this time, there were 193 principals and teachers in elementary schools in the county, including 65 graduates from normal schools, 10 from middle schools, 4 from high schools, and other schools. 43 people, 71 were not enrolled. At that time, teachers who graduated from new schools such as normal schools, middle schools, and high schools and engaged in teaching work accounted for $63.2 \%$ of the county's elementary school teachers. The teachers in Dongtai County elementary schools mainly came from new schools, and other sources of teacher resources were different. Some are transformed by rural private teachers, and some are senior school students, even non-illiterate groups who have only read a few days and learned some words.

Teachers who graduated from the Normal School have a new teaching mode and teaching methods. They use the set of educational models learned in the school to carry out teaching activities, and then cultivate new teachers for local education, such as graduated from Dongtai County. In the second year of the Republic of China (1913), Zhang Xiangzhang of the Teachers College was the principal of Dongtai No. 6 Elementary School. Teachers who have not received a new education are mostly old-style literati. Their teaching philosophy and teaching methods are more different than those cultivated by the new school. In addition, the new cultural movement under the cover of democratic and scientific thoughts "promotes new morality.", Against the impact of old morality "promoting new literature, opposing old literature", so the teaching content in the new textbooks cannot be perfectly controlled. Classes are still in the old-fashioned mode of private education. Some old gentlemen even don't know what chalk is, or they are not used to the writing habits of chalk. Instead, they are ground up and mixed with water.

Take a June Chinese lesson in Fu'an First Elementary School in the third education inspection of Dongtai County in the third year (1914) of the Republic of China as an example:

This lesson teaches reading. The evaluation of the professor was: "Failing to read in turn according to the level, the reading method is also inconsistent. Freedom of sound is very similar to private education. There is no change in teaching and teaching.,, 51 
It is worth noting that teachers of normal education account for only one third of the teachers in the county, which shows the extreme lack of teachers in the new education, and also proves the urgency of normal education. "To be prosperous in elementary schools, teachers must be sought. This must also be the case. In addition, the promotion of teachers, strict provincial regulations, is the establishment of the elementary school teacher's training center cannot be a day or postponed." County The quota of the teachers to be set up is four in the urban area (two in Dongtai and two in Heduo). At the city level, except for Fu'andong and Shenjiabang, each of which has three new ones, and the rest there are two cities in each city; except for Tangganghe Dongxiang and Bengfenghe Township, which have added one to the original one, the remaining one. However, due to the lack of funds and the importance of managers, the weak teachers and the growing number of students in Dongtai during this period were not directly proportional.

\section{Concluding Remarks}

Although the middle school education and normal education in Dongtai area emerged as the times require in the 31st year of Guangxu of Qing Dynasty (1905), the development process was very tortuous. The "Dongtai County Middle School and Additional High School" set up by Xuantong in third year (1912) and Guangxu thirty-one years (1905) was "Dongtai County Middle School and Normal School". After entering the Republic of China, the Department of Civil Affairs of Dongtai County took over the "two classes" of school affairs and changed the school to a school. Later, Dongtai County and the school supervised Yuantai He absconded with funds. The short-term Dongtai Normal Education came to an end with middle school education. Afterwards, Dongtai County's first supervisor, Chengye Yuan, ${ }^{53}$ once co-founded Dongtai Normal School. In the eighth year of the Republic of China (1919), Dongtai Normal University was founded by Wanqing Zhang No. 1 champion and industrialist Qian Zhang ${ }^{54}$ as a "Muli Normal Teacher", and Dongtai Normal Education was restored. Zhang Qian was originally from Haimen at Nantong. Because his mother was from Dongtai, so Dongtai was his mother's hometown, i.e. Muli. In return for his mother's filial piety, he resumed normal education in Dongtai in the eighth year of the Republic of China (1919). In his "Welcome to Dongtai," Zhang said: "Dongtai used to have a normal school, but it was discontinued a few years later. I was afraid that the supply of teachers would not be enough to meet demand. Therefore, I set up a Muli Normal School for the locality. The promotion of elementary schools the other day will give ordinary children the opportunity to receive education, and it will only depend on your mutual help.",55

It was not until 1924 that the Dongtai County Public Office re-established the Dongtai County Junior Middle School, marking the restoration of Dongtai Middle School education. Therefore, the rise and development of elementary education in Dongtai, although it is part of the macro, can reflect the whole education in the early years of the Republic of China. At the same time, squire celebrities, irrespective of returns, vigorously develop education, benefit mulberry, and invest in the future. In the 
fourteenth year of the Republic of China (1925), Shudong $\mathrm{Ge}^{56}$ founded the first Female Elementary School of Dongtai County ${ }^{57}$ in Fuzhuang Lane, Taicheng, and served as its principal. Two years later, Ge went to the director of education in Dongtai County, and transferred to Rulan Zhou ${ }^{58}$, who graduated from Jiangsu Provincial First Women's Normal School, to take over the post of female elementary school principal. Mr. Rulan Zhou is a Chinese teacher and has his own set of education methods. As the principal, she practiced and pushed forward, and at the same time, she focused on cultivating girls' practical ability and pioneering the trend.

In the fifteenth year of the Republic of China (1926), Gan Qian ${ }^{59}$ and Guojiang Zhou, Yaofu Ren, Ziwei Miao, Bofan Zhou, Jiezi Zhou, Zhiqing Niu and other educational circles planned to set up Anfeng Junior Middle School in Anfeng Gutang Lane. Gan Qian is from Anfeng. He participated in the imperial examination in his early years, graduated from the Liangjiang School of Law and Politics, and later entered the Beijing Normal School of Law and Politics. He served as President of the Jiangxi High Court. After resigning and returning to office, he served as the principal of Anfeng Higher Elementary School, and successively founded Anfeng Private Dexin Women's National School. After the outbreak of the Anti-Japanese War, Guangxi Zhou ${ }^{60}$, then acting principal of Shanghai Private Guangshi Middle School, returned to Taicheng to set up Shanghai Private Guangshi Middle School Dongtai Branch, which was set up Grades 610. Later the high school was merged into the Jiangsu Provisional No. 1 Middle School. After several relocations, the school was closed in 1940. It was rebuilt in 1947 after the victory of the War of Resistance against Japan, but it was suspended for only one year.

In the early years of the Republic of China, although there were certain limitations in elementary education in Dongtai, a large number of talents were cultivated. At the same time, its development has greatly promoted the normal education and elementary and secondary education.

Looking back at the development of Dongtai education at the end of the Qing Dynasty and the beginning of the Republic of China, it actually reflects the history of the development and change of Chinese education in the first half of the twentieth century. The literary and honest Dongtai City has nurtured Dongtai people with simple folk customs, and generations of education predecessors have actively participated in education. It has been passed down and worked harder to promote the ancient and honest Dongtai education to continue to emit more brilliant youth.

\section{Notes}

1. Edited by the Ming and Qing Archives Department of the Palace Museum, and preparing constitutional archives (Letter 2) at the end of the Qing Dynasty. "The Constitutional Editors Review the Constitution of Urban and Rural Local Autono- 
my and Urgently Propose the Constitution of the Election", Beijing: Zhonghua Book Company, 1979 edition, p. 725.

2. Edited by Qiu, Jiabiao, Education Status of Dongtai County, Shanghai: Commercial Press 1914 Edition, p. 1.

3. Cai, Yingchen (1859-1913), a character Shao Lan, a tribute student from the Qing dynasty, taught Tongzhou Confucianism. Later, he donated money to run the school, and set up tea tea Qixiu Wenshe and Qixiu Junior High School.

4. Edited by Qiu, Jiabiao, Education Status of Dongtai County, Shanghai: Commercial Press 1914 Edition, p. 1.

5. Ji, Cheng (1867-1928), the word Fengchi, Guangxu Gongsheng, was awarded the candidate training of Wenlin Lang. He had been a teacher of Jiangyin Nanjing College. He had taught in Luzhou Middle School, Dongtai County Middle School and Normal School.

6. Chen, Qishou (1863-1929), a character named Xingnan, has taught at Xixi Academy in Dongtai, Shangjiang Public School, Dongtai County Middle School, and Luzhoufu Middle School.

7. Chen, Ruyu (1844-1911), the character Bai Shi, a painter. He once taught at the Sanxian College of Dongtai City, Tangyin College, and the Middle School of Dongtai County.

8. Editor-in-chief of Chen Yuanhui, edited by Xingui Gui, edited by Tang Liangyan, "Educational System Evolution”, a compilation of materials on the history of modern Chinese education, Shanghai: Shanghai Education Press, 2007, p. 7.

9. Compiled by the Local History Compilation Committee of Jiangsu Province, Jiangsu Provincial Records • Educational Records (Part 1), Nanjing: Jiangsu Ancient Books Publishing House, 2000 edition, p. 151.

10. Compiled by the Dongtai County Chronicles Committee, Dongtai County Chronicles (1817-1911) Supplement (Vol. 1), 1983 edition, p. 24.

11. Yang Gongfu (1858-1933), whose name was Yin Yin, used words. Guangxu was a tributary, and was awarded to Hubei Candidate County. After the restoration of Dongtai in Xinhai, he was the first civil affairs director of the Dongtai County Civil Affairs Department.

12. Ding Litang (1861-1918), Zi Hesheng, was the chairman of Dongtai Business Branch, and served as commander and chief financial officer of the military and political branch after the Revolution of 1911.

13. Cui Yulin (1882-1954), Zi Zhongzhi, graduated from Jiangsu Liangjiang Superior Teachers College, and once served as the principal of Dongtai County First High School, the director of Dongtai County Class A Normal School, and the director of Dongtai Library. After that, he was a librarian of Jiangsu History and Culture Mu- 
seum.

14. Edited by Qiu Jiazheng, Education Status of Dongtai County, Shanghai: Commercial Press 1914 Edition, p. 1.

15. The same as the \#14.

16. Edited by Chen Xueyi, Selected Works of Modern Education in China, Beijing: People's Education Press, 1983, p. 323.

17. Edited by Qiu Jiabiao, Education Status of Dongtai County, Shanghai: Commercial Press 1914 Edition, p. 1.

18. According to a telegram from the Suncheon Times on February 21, 1914, the governors of the provinces were consulted on the local autonomy system.

19. According to the Statistical Office of the Governor's Office of Jiangsu Province in 1924, the "Provisional List of Governors of Sixty Counties in Jiangsu Province", "Political Yearbook of Jiangsu Province", page 41

20. Edited by Qiu Jiazheng, Education Status of Dongtai County, Shanghai: Commercial Press 1914 Edition, p. 1.

21. The same as the \#20.

22. The same as the \#20..

23. Compiled by the Dongtai County Chronicles Committee, Dongtai County Chronicles (from 1817 to 1911) Supplement (Vol. 1), 1983 edition, $p$.

24. Compiled by the Dongtai County Chronicles Committee, Dongtai County Chronicles (from 1817 to 1911) Supplement (Vol. 1), 1983 edition, $p$.

25. Edited by Qiu Jiayu, Educational Status of Dongtai County, Shanghai: Commercial Press 1914 Edition, p. 7.

26. Edited by Chen Xuexun, Cai Yuanpei's Opinions on Educational Guidelines, Selected Works of Modern Education in China, Beijing: People's Education Press, 1983, p. 323.

27. Edited by Qiu Jiabiao, Education Status of Dongtai County, Shanghai: Commercial Press 1914 Edition, p. 13.

28. Edited by Qiu Jiabiao, Educational Status of Dongtai County, Shanghai: Commercial Press 1914 Edition, p. 40.

29. Compiled by the Local History Compilation Committee of Jiangsu Province, Jiangsu Provincial Records • Educational Records (1), Nanjing: Jiangsu Ancient Books Publishing House, 2000 edition, p. 203.

30. Edited by Shu Xincheng, Modern History of Education in China (Part 1), Beijing: People's Education Press, 1961, p. 226. 
31. He Yuantai, name Jiping, a native of Shaoxing, Zhejiang, also serves as the supervisor of Dongtai County Middle School and the attached elementary school. In the second year of Xuantong (1910), the former head of the two churches, Han Lin Xia Yin, went to serve as the governor of Jiangxi. The two churches were managed by He. After the restoration of Dongtai County, He Yuantai fled with the money. According to Yang Yiyin's "The Civil Affairs of Dongtai County, Jiangsu Province" (1912 edition of the Commercial Press), he later recovered the bank silver carried by He's bank, accounting for 3,336 yuan (approximately RMB 4,488 yuan) and over-paid busy silver More than 30,000 yuan.

32. Edited by Qiu Jiabiao, Education Status of Dongtai County, Shanghai: Commercial Press 1914 Edition, p. 5.

33. Sourne et al., Xue Zhengquan Volume 47 Beijing: Zhonghua Book Company 2015 Edition.

34. Wang Huai, name Xing Yuan, was the treasurer of Dongtai County Office in the early years of the Republic of China, and later served as the academic director of Heduo City, Dongtai County.

35. Lu Rong, name Yin Nan. Guangxu was born in nine years. In the three years of the Republic of China (1914), he served as chairman of the Education Committee of Dongtai County. In the tenth year of the Republic of China (1921), Dongtai established the Bureau of Rehabilitation and presided over the compilation of "Dongtai County Records."

36. Edited by Jiangsu Dongtai Middle School, Anthology of Centennial Anniversary of Jiangsu Dongtai Middle School, 2005 edition, p.274.

37. Editor-in-Chief of Chen Xuezheng, Reference Materials of Modern Chinese History of Education Teaching (Volume One), Beijing: People's Education Press, 1986, pp. 758-759.

38. Zhou Guojiang (? -1930), Zibaichuan, graduated from Liangjiang Teachers College, former director of persuasion, principal of private Shanyu Junior High School, local judge of two provinces of Jiangxi and Anhui, and later participated in the establishment of Dongtai Anfeng Middle School.

39. Miao Ziwei (1891-1943), named Xi Ping, graduated from the Nanjing University of Law and Political Science with a word line. In the early years of the Republic of China, he served in the government of Leping County, Jiangxi, and was reemployed in the Commercial Press. He was the vice principal of Dongtai Anfeng High Elementary School.

40. Ren Yaofu, known as Houyi, used to be a teacher of Chinese culture. He was the president of the East Taiwan Chamber of Commerce in 1920 (1920) and participated in the establishment of Dongtai Anfeng Middle School. 
41. Edited by Qiu Jiabiao, Educational Status of Dongtai County, Shanghai: Commercial Press 1914 Edition, p. 1, p. 17.

42. Edited by Qiu Jiabiao, Education Status of Dongtai County, Shanghai: Commercial Press 1914 Edition, p. 3.

43. Edited by Qiu Jiabiao, Education Status of Dongtai County, Shanghai: Commercial Press 1914 Edition, p. 18.

44. Edited by Qiu Jiabiao, Educational Status of Dongtai County, Shanghai: Commercial Press 1914 Edition, p. 19.

45. Edited by Qiu Jiabiao, Educational Status of Dongtai County, Shanghai: Commercial Press 1914 Edition, p. 14.

46. Edited by Qiu Jiabiao, Education Status of Dongtai County, Shanghai: Commercial Press 1914 Edition, p. 1.

47. Compiled by the Dongtai County Chronicles Committee, Dongtai County Chronicles (1817 to 1911) addendum (in Chinese), 1983 edition, pp. 286-306.

48. Zhou Jiahua (1879-1959), a good character, and a scholar of Guangxu, successively served as secretary of the Guangdong Southern Military Government and the Government of the Jiangsu Province of the Republic of China, and later was the vice chairman of the CPPCC of Dongtai County and a librarian of Jiangsu Province.

49. Edited by Shu Xincheng, Modern History of Education in China (Part 1), Beijing: People's Education Press, 1961, p. 426.

50. Edited by Jiang Chunjiao, History of Chinese Private Education, Taiyuan: Shanxi Education Press, 2017, p. 202.

51. Edited by Qiu Jiabiao, Education Status of Dongtai County, Shanghai: Commercial Press 1914 Edition, p. 51.

52. Edited by Qiu Jiabiao, Education Status of Dongtai County, Shanghai: Commercial Press 1914 Edition, p. 1.

53. Yuan Chengye (1866-1928), name Boqin, Jiansheng in the first year of Xuantong. He was the first inspector of Dongtai County, a member of the Provincial Education Society, and a reviewer of the Xiuzhi Bureau. He devoted his life to local literature and history and edited and published books.

54. Zhang Qian (1853-1926), name Jizhi, was born in Nantong, Jiangsu. Scholars in the late Qing Dynasty, modern industrialists, politicians, and educators.

55. Compiled by the Compilation Committee of Zhang Ye's Complete Works, Zhang Ye's Complete Works (Volume 4 On Speeches), Shanghai: Shanghai Dictionary Publishing House 2012, p. 458. 
56. Ge Shudong (1887-1937), name Shaojia, graduated from Nantong Normal University, and successively taught at Dongtai County High Elementary School and Women's Elementary School. He later founded Dongtai County First Women's Elementary School and served as Superintendent and Director of Dongtai County Education Bureau.

57. Dongtai County Girls' Elementary School was founded in 1925, which is one of the predecessors of Dongtai Experimental Elementary School today.

58. Zhou Rulan (1902-1978), name Jinzhi, graduated from Jiangsu Provincial First Women's Normal University, once served as the principal of Dongtai County First Women's Elementary School, and later was the representative of the First, Second, Third, Fourth, Fifth and Sixth National People's Congress of Dongtai, CPPCC members.

59. Qian Qian (1882-1944), name Shaobai, Guangxu Xiucai, graduated from Liangjiang School of Law and Politics, and once served as president of the Jiangxi High Court. He later served as the principal of Anfeng Higher Elementary School, and later founded the private Dexin Women's National School and Anfeng Junior High School.

60. Zhou Guangxi (1908-1994), graduated from Guanghua University, was the acting principal of Shanghai Private Guangshi Middle School, and later founded Shanghai Private Guangshi Middle School Dongtai Branch during the Anti-Japanese War.

\section{References}

Chen Yuanhui, editor, Tong Xingui, Tang Liangyan, "Educational System Evolution", a compilation of materials on the history of modern Chinese education, Shanghai: Shanghai Education Press, 2007.

Compiled by the Compilation Committee of Zhang Qian's Complete Works, Complete Works of Zhang Qian (Speaking Speeches in Volume 4), Shanghai: Shanghai Dictionary Publishing House 2012.
Daibing, Elementary Education in Northeast China (1905-1918), Late Qing Dynasty and Early Republic of China, Northeast Normal University, May 2011.

Edited by Chen Xuexun, Reference Materials for Modern Chinese History of Education Teaching (Volume One), Beijing: People's Education Press, 1986.

Edited by Chen Xuexun, Selected Works of Modern Education in China, Beijing: People's Education Press, 1983. 
Edited by Dongtai County Chronicles Committee, Dongtai County Chronicles (from 1817 to 1911) addendum, 1983 edition.

Edited by Jiangsu Dongtai Middle School, anthology of centennial celebrations of Jiangsu Dongtai Middle School, 2005.

Edited by Qiu Jiabiao, Educational Status of Dongtai County, Shanghai: Commercial Press, 1914 Edition.

Edited by Shu Xincheng, Modern History of Education in China (Part 1), Beijing: People's Education Press, 1961.

Edited by the Chief Editors Committee of China Encyclopedia, China EncyclopediaEducation Volume, Beijing: China Encyclopedia Press, 1985.

Edited by the History Department of Yangzhou Teachers College, historical materials of Jiangsu area during the Revolution of 1911, Nanjing: Jiangsu People's Publishing House, 1980 edition.

Edited by the Local History Compilation Committee of Jiangsu Province, Jiangsu Provincial Records $\bullet$ Educational Records (Part 1), Nanjing: Jiangsu Ancient Books Publishing House, 2000 edition.

Edited by the Statistics Department of the Office of the Governor of Jiangsu Province, Jiangsu Province Political Yearbook, 1924.
Jiang Chunjiao. History of Chinese Private Education, Taiyuan: Shanxi Education Press, 2017.

The Ming Dynasty and Qing Dynasty Archives Department of the Palace Museum, prepared the constitutional archives materials in the late Qing Dynasty (volume two), "Constitutional Review and Examination Committee to review the regulations of urban and rural local autonomy and urgently plan to fold the electoral regulations", Beijing: Zhonghua Book Company, 1979 edition.

Xiao Shengyao, Jiangsu Primary School Education Research, Late Qing Dynasty and Early Republic of China, Yangzhou University, April 2011.

Yang Yiyin, Civil Affairs of Dongtai County, Jiangsu, Shanghai: Commercial Press 1912 Edition.

Zhao Yingxia, Research on the Historical Evolution of Sinology Education in Elementary and Middle Schools in the Late Qing Dynasty and the Republic of China: Taking the Course as the Center of Inspection, Hebei University, May 2016.

Zhu Xiaonan, Controversy over the County, City, and Township System in the Early Republic of China: Taking Jiangsu's "New System" and "Old Chapter" as Examples, Jiangxi Social Science, September 2017. 